\title{
Literature Review: Kemampuan Anak Berkebutuhan Khusus Melakukan Kebersihan Diri
}

\author{
Ita Pursitasari ${ }^{1}$, Allenidekania ${ }^{2}$ \\ ${ }^{1}$ Program Studi Keperawatan, Politeknik Kesehatan Bandung, Indonesia \\ ${ }^{2}$ Departemen Keperawatan Anak, Universitas Indonesia Depok, Indonesia \\ Email: ithapur@gmail.com
}

\begin{abstract}
Literature Review: Needs of Children with Special Needs. The number of the child with special needed which is quite alarming is one of the health problems that occur in children. The purpose of this writing is to find out the family support in maintaining children with special needs in performing personal hygiene. The child with special needed have health problems or obstacles in various circumstances and classifications, such as lack of interaction in community and school activities, limited activities, emotional and behavioral delays, and limitations of intellectual development. These problems can cause an impact on children's independence, one of which is self-care. In order for the child with special needed to be able do personal hygiene independently, support from the family is needed. The support provided is social support consisting of emotional, instrumental, appreciation and information support.
\end{abstract}

Keywords: Family support, Personal hygiene, The child with special needed

\begin{abstract}
Abstrak: Literature Review: Kemampuan Anak Berkebutuhan Khusus Melakukan Kebersihan Diri. Jumlah ABK yang cukup memprihatinkan merupakan salah satu masalah kesehatan yang terjadi pada anak. Tujuan dari penulisan ini yaitu untuk mengetahui dukungan keluarga dalam memandirikan anak berkebutuhan khusus dalam melakukan kebersihan diri. ABK memiliki masalah atau hambatan kesehatan dalam berbagai keadaan dan klasifikasi, seperti kurang berinteraksi dalam kegiatan masyarakat dan sekolah, keterbatasan aktivitas, keterlambatan perilaku dan emosional, dan keterbatasan perkembangan intelektual. Masalah tersebut dapat menyebabkan dampak terhadap kemandirian anak, salah satunya yaitu dalam perawatan diri. Agar ABK dapat melakukan kebersihan diri secara mandiri diperlukan dukungan dari keluarga. Dukungan yang diberikan merupakan dukungan sosial yang terdiri dari dukungan emosional, instrumental, penghargaan dan informasi.
\end{abstract}

Kata Kunci: Dukungan keluarga, Kebersihan diri, Anak berkebutuhan khusus

\section{PENDAHULUAN}

Anak berkebutuhan khusus merupakan anak yang memiliki risiko untuk mengalami penyakit kronis, gangguan perkembangan, gangguan emosional, kelainan atau cacat fisik serta membutuhkan pelayanan kesehatan yang lebih dari anak pada umumnya (Hockenberry and Wilson, 2009). Anak berkebutuhan khusus menurut Kementrian Pemberdayaan Perempuan dan Perlindungan Anak Republik Indonesia (2013) adalah Anak yang mengalami keterbatasan atau keluarbiasaan, baik fisik, mental-intelektual, sosial, maupun emosional, yang berpengaruh secara signifikan dalam proses pertumbuhan atau perkembangannya dibandingkan dengan anak-anak lain yang seusia dengannya. Sedangkan menurut Desiningrum (2016) anak berkebutuhan khusus adalah anak dengan karakteristik khusus yang berbeda dengan anak pada umumnya tanpa selalu menunjukkan pada ketidakmampuan mental, emosi atau fisik.

Hasil analisis WHO (2011) diketahui bahwa $15,3 \%$ populasi dunia (sekitar 978 juta orang dari 6,4 milyar estimasi jumlah penduduk tahun 2004) mengalami disabilitas sedang dan $2,9 \%$ atau sekitar 185 juta mengalami disabilitas parah, sedangkan pada populasi rentang umur 014 tahun prevalensi berturut-turut sekitar 5,1\% (93 juta orang) dan $0,7 \%$ (13 juta orang). Menurut Kemenkes (2013) prevalensi anak berkebutuhan khusus yaitu sebanyak 6,2\%. Angka anak disabilitas di Indonesia yang terdapat di berbagai provinsi cukup memprihatinkan. Angka ABK tertinggi terdapat di provinsi Sulawesi Tengah 7,0\%, Gorontalo $5,4 \%$, Sulawesi Selatan 5,3\%, banten 5,0\%, 
Sumatera Barat 5,0\%. Sedangkan di pulau Jawa, Jawa Barat mendapatkan posisi kelima setelah DKI Jakarta, DI Yogyakarta, Jawa Timur dan Jawa Tengah yaitu sebanyak 2,8\% (Kemenkes, 2018).

ABK memiliki masalah kesehatan dan keterbatasan. Sejalan dengan hal tersebut, Kementerian Pemberdayaan Perempuan dan Perlindungan Anak (2013) menyebutkan bahwa jenis ABK yaitu anak disabilitas penglihatan, anak disabilitas pendengaran, anak disabilitas intelektual, anak disabilitas fisik, anak disabilitas sosial, anak dengan gangguan pemusatan perhatian dan hiperaktivitas (GPPH) atau attention deficit and hyperactivity disorder (ADHD), anak dengan spectrum autisma (autism spectrum disorder/ASD), anak dengan gangguan ganda, anak lamban belajar (slow learner), anak dengan kesulitan belajar khusus (specific learning disabilities), anak dengan gangguan kemampuan komunikasi, anak dengan potensi kecerdasan dan atau bakat istimewa.

Masalah seringkali ditemukan pada ABK, pada anak dengan keterbatasan intelektual ditemukanadanya ketidakmampuan dalam mengontrol emosional dan sosial, kosa kata yang sedikit, reaksi yang lambat, rentang perhatian pendek, ketidakmampuan untuk melakukan generalisasi, kesulitan dalam berbahasa serta membutuhkan hal-hal yang sederhana dalam kehidupan sehari-hari (Maria et al. 2013). Sedangkan masalah perilaku yang muncul pada anak dengan keterbatasan intelektual, yaitu stereotif, impulsive, iritabel dan agesif (Koshali, 2013). Masalah yang muncul pada anak dengan Cerebral Palsy yaitu adanya keterbatasan aktivitas disertai dengan gangguan sensasi, kognisi, komunikasi, persepsi dan perilaku (Dambi and Jelsma 2014). Menurut penelitian yang dilakukan oleh Tan., et al, (2014) masalah lain yang bisa ditemukan pada anak dengan Cerebral Palsy yaitu adanya keterbatasan anggota gerak sehingga anak menghadapi tantangan dalam kehidupan sehari-hari, dimana mereka mengalami masalah kelenturan, kontraktur, dyskinesia, dan kerusakan sensorik sehingga dapat mengganggu dalam melakukan kegiatan sehari-hari seperti berpakaian, menulis,dan lain sebagainya.

Melakukan aktivitas sehari-hari merupakan hal penting dalam kehidupan. Bal, Kim, Cheong, \& Lord, (2015) menyebutkan bahwa aktivitas sehari-hari seperti kebersihan pribadi, makan, manajemen uang dan waktu merupakan hal penting untuk bisa hidup mandiri. Sedangkan Wertalik dan Kubina (2017), menyebutkan bahwa mayoritas pada anak autis mengalami ketidakmampuan dalam perawatan diri, makan, dan berpakaian. Penelitin lain yang dilakukan oleh Ramawati (2011), menyebutkan bahwa anak tunagrahita yang mampu melakukan aktivitas perawatan diri (kebersihan diri, makan, minum, berpakaian, mobilisasi, pergerakan, sosialisasi) tanpa bantuan dari orang lain sebanyak 3,1\%. Ananditha (2013) menyebutkan bahwa kemampuan anak tuna grahita dalam melakukan toileting sebanyak $45,5 \%$ dan anak sepenuhnya tergantung pada orang tua dan guru dalam melakukan BAB dan BAK .

Menurut Demographics, Rehabilitation Research and Training Center on Disability Statistics (2016), kemampuan merawat diri secara mandiri pada individu yang mengalami disabilitas yaitu sekitar $15.6 \%$. Kemenkes (2013) menyebutkan bahwa prevalensi disabilitas yang sulit membersihkan tubuh yaitu sebanyak $4.1 \%$ ringan, $1.1 \%$ sedang dan $0.5 \%$ berat, sedangkan yang sulit untuk mengenakan pakaian yaitu sebanyak $3.9 \%$ ringan, $1.0 \%$ sedang dan $0.4 \%$ berat.

Perawatan diri yang dilakukan dengan baik akan berdampak terhadap kesehatan dan meningkatkan kualitas hidup. Pemeliharaan kebersihan pribadi harus diajarkan sejak kecil, dimana hal itu akan menyebabkan masa kecil yang sehat, untuk dewasa yang sehat, untuk pengembangan nilai-nilai positif tentang kesehatan dan penggunaan layanan kesehatan (Khatoon et al. 2017). Menurut Limeres (2014), salah satu penyakit yang ditimbulkan akibat dari kurangnya perawatan diri yaitu adanya penyakit pada daerah mulut, hal ini disebabkan oleh kebersihan mulut yang buruk akibat tidak menggosok gigi. Penyakit pada mulut yang sering muncul yaitu gingivitis, periodontitis, dan karies (Limeres et al. 2014) Menurut penelitian yang dilakukan oleh MazecaiteVaitilaviciene and Owens (2018), dengan metode retrospektif disebutkan bahwa kesehatan gigi pada ABK di Lithuania sangat buruk, yaitu sebagian besar ABK memiliki gigi yang rusak. Masalah lain yang muncul akibat kurangnya perawatan diri yaitu ketidaknyamanan yang diakibatkan oleh pakaian yang kotor akibat ketidakmampuan dalam toileting, selain itu ABK menjadi korban bullying baik secara fisik ataupun verbal (Francis, Mannion, and Leader 2017). Kemampuan perawatan diri merupakan salah satu keterampilan yang harus dikuasai oleh ABK. Menurut Kemendikbud (2014) kemampuan perawatan diri merupakan salah satu pengetahuan dan keterampilan sebagai mata pelajaran kekhususan bagi siswa berkebutuhan khusus. Agar ABK dapat melakukan perawatan 
diri secara mandiri tentu saja diperlukan peran dan dukugan dari keluarga khususnya orangtua. Menurut penelitian yang dilakukan oleh Lestari, Yani \& Nurhidayah (2018), peran perawatan orang tua terhadap ABK masih rendah yaitu sebanyak $16,1 \%$ serta dukungan keluarga dan sosial sebanyak 12,9\%. Menurut Falico (1998) dalam Friedman (2010) keluarga besar lebih kuat dan lebih aktif dalam memberikan dukungan baik secara emosional maupun instrumental Mundhenke et al. (2014), menyebutkan bahwa dukungan sosial sangat dibutuhkan oleh ABK, salah satunya yaitu penelitian yang dilakukan terhadap anak dengan gangguan intelektual membutuhkan dukungan instrumental dari orang tuanya, misalnya dalam melakukan perawatan diri, selain orang tua mereka menerima dukungan instrumental dari saudara kandung atau kerabat dekat lainnya.

Tujuan dari penulisan ini yaitu untuk mengetahui dukungan keluarga dalam memandirikan anak berkebutuhan khusus dalam melakukan kebersihan diri. Sedangkan manfaat dari penulisan ini yaitu agar dapat bermanfaat dalam pengembangan ilmu keperawatan yang berkaitan dengan $\mathrm{ABK}$, khususnya tentang dukungan keluarga dengan kemampuan melakukan kebersihan diri serta menjadi informasi bagi orang tua, bagaimana orang tua dapat mengaplikasikan pengetahuan tentang dukungan keluarga pada ABK agar anak mampu melakukan kebersihan diri secara mandiri

\section{Kategori Anak Berkebutuhan Khusus}

Direktorat Pembinaan Sekolah Luar Biasa atau Direktorat PSLB, mengklasifikasikan anak berkebutuhan khusus (ABK) dalam beberapa klasifikasi sebagai berikut (Suparno dan Purwanto, 2007):

a. Tuna netra atau anak dengan gangguan penglihatan ( kebutaan dan low vision), ditempatkan dalam SLB kategori A atau SLB A

b. Tuna rungu/tuna wicara atau anak dengan gangguan pendengaran dan gangguan bicara (bisu), ditempatkan dalam SLB B

c. Tuna grahita atau anak yang memiliki retardasi mental (memiliki skor kecerdasan/IQ dibawah 100), ditempatkan dalam SLB C

d. Tuna daksa atau anak yang memiliki cacat fisik baik yang didapat anak dari lahir atau yang disebabkan oleh trauma/kecelakaan, ditempatkan di SLB D

e. Tuna laras atau anak yang mengalami gangguan emosi dan sosial (anak yang memiliki disruptive behavior), ditempatkan dalam SLB E

f. Autisme atau anak yang mengalami/memiliki karakter spectrum autis, ditempatkan dalam SLB F atau SLB autism

g. Tuna ganda atau anak-anak yang mengalami kecacatan atau gangguan lebih dari satu, ditempatkan dalam SLB G.

Selain klasifikasi berdasarkan jenis pendidikan luar biasa yang berkembang saat ini, Direktorat PSLB juga mengklasifikasikan anak berkebutuhan khusus lainnya, yaitu:

a. Anak dengan HIV-AIDS

b. Anak berbakat dengan kecerdasan di atas rata-rata dan keterampilan luar biasa, anak seperti ini disebut dengan gifted dan talented

c. Anak dengan kesulitan belajar seperti disleksia, diskalkulia, dan lain sebagainya.

d. Anak korban penyalahgunaan narkotika

e. Anak indigo, yaitu anak yang memiliki kemampuan paranormal.

Anak-anak tersebut saat ini memang tidak dimasukkan ke dalam sebuah sekolah atau jenis pendidikan khusus, namun biasanya dimasukkan di sekolah biasa dengan perlakuan atau pola pendidikan yang disesuaikan dengan kemampuan anak.

\section{PEMBAHASAN}

\section{Perawatan Diri Anak Berkebutuhan Khusus}

Kemampan melakukan perawatan diri secara mandiri merupakan salah satu keterampilan yang harus dikuasai oleh ABK. Menurut Bal et al. (2015) dalam Daily living skills in individuals with autism spectrum disorder from 2 to 21 years of age anak-anak dengan keterampilan bahasa resepif yang lebih tinggi menunjukan kemampuan melakukan aktivitas sehari-hari lebih cepat $(p<0,001)$ dibandingkan dengan anak-anak ASD $(p<0,05)$. Wilson et al. (2009) dalam "Penile hygiene: puberty, paraphimosis and personal care for men and boys with an intellectual disability"menyebutkan bahwa anak dengan keterbatasan intelektual membersihkan penis dengan cara menarik kulup setiap hari sebanyak 92,5\% dan $7,5 \%$ yang membersihkan penis dengan cara tidak menarik kulup dan sebanyak $60,4 \%$ tidak mengetahui untuk menarik kulup saat membersihkan penis. Sedangkan menurut penelitian yang dilakukan oleh Limeres et al. (2014) pada anak berkebutuhan khusus 
didapatkan data frekuensi menyikat gigi dua kali sehari dilakukan oleh 19 orang $(31,7 \%)$ dan tiga atau lebih dari sehari sebanyak 18 orang (30\%) dan yang jarang melakukan gosok gigi sebanyak 10 orang $(16,7 \%)$, menggunakan sikat gigi manual sebanyak $40 \%$ subjek. Sikat gigi manual adalah sebanyak 48 orang $(80 \%)$ dan yang menggunakan sikat gigi listrik sebanyak 7 orang $(11,7 \%)$, waktu yang digunakan untuk menggosok gisi kurang dari 1 menit sebanyak $(36,7 \%)$, antara satu dan 3 menit $(35 \%)$ dan tiga menit atau lebih $(28,3 \%)$, pasta gigi digunakan oleh $80 \%$ sampel dan $28,3 \%$ ditambahkan menyikat gigi dengan menggunakan obat kumur, penggantian sikat gigi dilakukan empat kali atau lebih dalam setahun sebanyak $45 \%$, sedangkan pengasuh menunjukkan bahwa sikat gigi diganti ketika menunjukkan tanda-tanda kerusakan pada 13 kasus $(21,6 \%)$, Hampir sepertiga dari subyek (30\%) menyikat gigi tanpa bantuan, sedangkan yang dibantu sebanyak $31,7 \%$ kasus dan sebanyak 38,3\% yang menyikat gigi sendiri tapi masih dalam pengawasan.

Masalah kesehatan akan muncul yang diakibatkan oleh kurangnya perawatan diri. Penelitian yang dilakukan oleh MazecaiteVaitilaviciene and Owens (2018), dengan metode retrospektif disebutkan bahwa kesehatan gigi pada ABK di Lithuania sangat buruk, dimana $72 \%$ dari ABK memiliki 5 gigi yang rusak dan sebanyak $27 \%$ dari $\mathrm{ABK}$ memiliki 10 gigi yang rusak. Menurut Wilson et al. (2009) dalam "Penile hygiene: puberty, paraphimosis and personal care for men and boys with an intellectual disability" pada anak dengan keterbatasan intelektual menyebutkan bahwa membersihkan penis dengan cara menarik kulup setiap hari sebanyak $92,5 \%$ dan $7,5 \%$ yang membersihkan penis dengan cara tidak menarik kulup dan sebanyak 60,4\% tidak mengetahui untuk menarik kulup saat membersihkan penis. Selain itu didapatkan data adanya kelainan pada anak-anak yaitu phimosis atau para phimosis sebagai akibat dari tidak membersihkan penis dengan menarik kulupnya. Menurut penelitian yang dilakukan oleh Karyati (2014) ditemukan data bahwa sebanyak 144 orang $(94,5 \%)$ mengalami keputihan fisiologis dan sebanyak 7 orang $(4,5 \%)$ mengalami keputihan patologis.

Masalah kesehatan anak berkebutuhan khusus khususnya anak dengan keterbatasan intelektual (ID) biasanya memiliki kebersihan mulut yang kurang sehingga memiliki kecenderungan karies gigi yang lebih tinggi dibandingkan dengan anak-anak yang lain (Makkar et al. 2019). Anak dengan cerebral palsy secara umum memiliki angka kejadian karies gigi yang tinggi dan kebersihan mulut yang rendah dibandingkan dengan anak-anak pada umumnya (Sinha N., Singh B., Chhabra K. G. \& Patil S., 2015). Faktor penyebab terjadinya penyakit gigi yang tinggi pada anak cerebral palsy yaitu disebabkan karena adanya antoksidan yang lebih rendah pada air liur, kadar asam salisilat dan osmolalitas air liur yang lebih tinggi serta perubahan protein dari saliva mulut (Leite et al. 2013; Santos et al. 2014; Subramaniam et al. 2014; Santos et al. 2016). Sedangkan menurut Makkar et al. (2019) dalam A Cross Sectional Study to Evaluate the Oral Health Status of Children with Intellectual Disabilities in the National Capital Region of India (Delhi-NCR) anak dengan down syndrome memiliki kerusakan periodontal yang parah dan kolonisasi pathogen oral yang lebih tinggi dibandingken dengan anak autism pada umumnya, dan anak-anak autisme memiliki kesehatan mulut yang buruk dibandingkan dengan anak-anak tanpa autisme.

Keterampilan ABK dalam melakukan perawatan diri masih terbatas. Penelitian yang dilakukan oleh Wertalik and Kubina (2017), yang dilakukan terhadap anak autisme menunjukkan bahwa keterampilan tentang perawatan diri masih terbatas, seperti mandi, mencuci rambut, dan berpakaian. Sedangkan penelitian lain yang dilakukan oleh Khatoon et al (2017) yang dilakukan terhadap 800 siswa di sekolah, hanya $38 \%$ anak-anak yang mengetahui cara merawat rambut dengan baik adalah merupakan bagian dari kebersihan pribadi, sebanyak $50,5 \%$ dari siswa sepakat bahwa menggigit kuku dengan gigi itu tidak sehat untuk gigi kita, sedangkan sebanyak $75 \%$ siswa setuju bahwa tidak perlu mencuci tangan ketika tidak ada kotoran yang terlihat, sebanyak $77 \%$ dari siswa melakukan mandi di alternatif hari dan hanya $13 \%$ dari siswa melakukan mandi setiap hari, dan mengganti pakaian di hari alternatif sebanyak $79,5 \%$ siswa.

\section{Dukungan Keluarga}

ABK agar mampu melakukan perawatan diri dalam kehidupan sehari-hari tentu saja diperlukan dukungan keluarga terutama dari orangtua. Mundenke (2014) menyebutkan bahwa dukungan sosial sangat dibutuhkan oleh ABK, salah satunya yaitu penelitian yang dilakukan terhadap anak dengan gangguan intelektual membutuhkan dukungan instrumental dari orang tuanya, misalnya dalam melakukan perawatan diri, selain orang tua mereka menerima dukungan instrumental dari saudara kandung atau kerabat dekat lainnya. 
Menurut Aldersey., et al. (2016) dukungan terbesar yaitu material/instrumental, dimana keluarga sangat membutuhkan kebutuhan dasar seperti makanan, tempat tinggal dan perawatan kesehatan. Sedangkan penelitian lain yang dilakukan oleh Rinald and Mirenda (2012), pada orang tua dengan anak autisme, dimana orang tua diajarkan bagaimana cara melatih toileting pada anak dengan cara menetapkan jadwal untuk toilet sitting, meningkatkan asupan cairan, penguatan positif untuk eliminasi di toilet, bimbingan untuk mengajarkan self initiation, dan hukuman jika gagal melakukan toileting, dari semua langkah tersebut didapatkan hasil bahwa semua anak mampu menggunakan toilet di tempat lain seperti rumah saudara, sekolah dan tempat umum.

Anak dengan keterbatasan intelektual mengalami keterbatasan dalam berinteraksi sosial dan memahami emosi. Menurut penelitian yang dilakukan pada anak dengan keterbatasan intelektualdalam Emotion perception from situation: Comparing the abilities of children with intellectual disability and children with regular development, dengan adanya masalah sosial emosional pada anak denganketerbatasan intelektual menyebabkan kesulitan seperti berkomunikasi, memahami norma sosial, dan kurang mampu membaca emosi orang lain atau isyarat sosial (Ališauskaitè, \& Butkienė, 2013). Sumber utama dukungan sosial yang diidentifikasi adalah orangtua atau keluarga, teman, guru, dan pelatih. Orangtua dapat berperan sebagai sumber dukungan instrumental (bantuan fisik, seperti membantu pekerjaan rumah atau menyelesaikan masalah di sekolah) serta dukungan emosional (seperti menjadi orang kepercayaan bagi anak untuk mengekspresikan emosi mereka), anggota keluarga lainnya seperti saudara kandung dan kakek-nenek juga memiliki peran yang sama,teman-teman bisa berperan sebagai sumber utama untuk dukungan emosional, dimana anak dengan keterbatasan intelektual bisa menceritakan tentang masalahnya, berkomunikasi dan bersenang- senang dengan temannya, selain itu guru dan pengasuh dapat juga berperan dalam memberikan dukungan instrumental (Hapke, 2015).

Dukungan keluarga khususnya orangtua sangat dibutuhkan dalam memandirikan anak melakukan perawatan diri. Penelitian yang dilakukan oleh Mundhenke et al. (2014), dalam Experiences of Swedish Children with Disabilities: Activities and Social Support in Daily Life, beberapa anak dengan keterbatasan fisik dan dengan keterbatasan intelektual membutuhkan dukungan instrumental dari orang tua mereka, misalnya dalam perawatan pribadi, selain itu mereka menerima dukungan instrumental dari saudara kandung atau kerabat dekat lainnya seperti dari kakek dan nenek. Selain dukungan instrumental pada anak dengan keterbatasan intelektual dan fisik membutuhkan dukungan informasi dari orang tuanya dimana mereka mengalami kesulitan tentang konsep waktu, sehingga orang tua harus mengingatkan di mana mereka seharusnya siang hari danapa yang harus mereka lakukan setelah sekolah, sedangkan saat mengerjakan pekerjaan rumah, anak dengan keterbatasan fisik menerima dukungan instrumental maupun informatif dari orang tua dan teman saat dibutuhkan, dan saat bermain mereka menerima dukungan instrumental dan emosional dari orang tua dan teman (Mundhenke et al. 2014).

\section{SIMPULAN}

ABK dalam melakukan kebersihan diri diperlukan dukungan dari keluarganya, baik itu dari orangtua atau saudara terdekatnya, karena ABK mengalami keterbatasan baik itu dari fisik ataupun intelektual. Dengan adanya dukungan dari keluarganya diharapkan ABK mampu melakukan kebersihan diri secara mandiri sehingga mereka dapat menjalani kehidupan seperti anak-anak pada umumnya.

\section{DAFTAR PUSTAKA}

Aldersey, Tumbull, \& Tumbull. (2016). Family supportin kinshasa, democratic republic of the congo. Jurnal of Policy and Practice in Intellectual Disabilities, 13, 23-32.

Ališauskaite, I., \& Butkienè, D. (2013). Emotion perception from situation: Comparing theabilities of children with intellectual disability and children with regular development. Special Education, 37-46.

Ananditha. (2013). Pengaruh Pembelajaran dengan Media Buku Cerita Bergambar Terhadap Activity Daily Living: Toileting Pada Anak Tunagrahita (Unpublished Thesis, Universitas Indonesia). Depok. 
Bal, V. H., Kim, S. H., Cheong, D., \& Lord, C. (2015). Daily living skills in individuals with autism spectrum disorder from 2 to 21 years of age. Autism, 19(7), 774-784. https://doi.org/10.1177/136236131557584 0

Dambi, J. M., \& Jelsma, J. (2014). The impact of hospital-based and community based models of cerebral palsy rehabilitation: A quasi-experimental study. $B M C$ Pediatrics, 14(1).

https://doi.org/10.1186/s12887-014-03018

Desiningrum. (2016). Psikologi Anak Berkebutuhan Khusus. Yogyakarta: Psikosain.

Demographics, Rehabilitation Research and Training Center on Disability Statistics (2016). Disability Statistics Annual Report.

https://disabilitycompendium.org/sites/def ault/files/user-

uploads/2016_AnnualReport.pdf.

Francis, Kady, Arlene Mannion, and Geraldine Leader. 2017. "The Assessment and Treatment of Toileting Difficulties in Individuals with Autism Spectrum Disorder and Other Developmental Disabilities. "Review Journal of Autism and Developmental Disorders 4 (3): 190 204. https://doi.org/10.1007/s40489-0170107-3.

Friedman. (2010). Keperawatan keluarga: Teori dan praktek (Achir Yani S. Hamid, Penerjemah.). Jakarta: EGC.

Hapke, Laura. 2015. Social Support Networks Among Children with Intellectual and Developmental Disabilities. (Theses, University of New Hampshire).

Hockenberry, M.J. \& Wilson, D. (2009). Wong's Essentials of pediatric nursing. (8th ed.). St. Louis: Mosby Elsevier.

Kementrian Pemberdayaan Perempuan dan Perlindungan Anak. (2013). Panduan penanganana anak berkebutuhan khusus bagi pendamping (orangtua, keluarga dan masyarakat). Kementrian Perlindungan Anak dan Perempuan: Jakarta.

Kemenkes. (2013). Riset Kesehatan Dasar. Jakarta: Kemenkes.

Kemenkes. (2018). Laporan RISKESDAS. Jakarta: Kemenkes

Kemendikbud. (2014). Peraturan Menteri Pendidikan dan Kebudayaan Repubik Indonesia no 157 tahun 2014 tentang kurikulum pendidikan khusus. Kemendikbud: Jakarta.
Khatoon, Ruby, Beena Sachan, MohsinAli Khan, and JP Srivastava. (2017). Impact of School Health Education Program on Personal Hygiene among School Children of Lucknow District. Journal of Family Medicine and Primary Care 6 (1): 97. https://doi.org/10.4103/2249-4863.214973.

Koshali, Afsaneh Khajevand. (2013). The Study of Behavior Problem in Children with Mental Disabilities. European Journal of Experimental Biology. Vol 3(3), 542-547

Lestari, Yani \&Nurhidayah. (2018). Kebutuhan Orang Tua dengan Anak Disabilitas. JNC Volume 1 Nomor 1 February 2018

Limeres, J., F. Martínez, J. F. Feijoo, I. Ramos, A. Liñares, and P. Diz. (2014). A New Indicator of the Oral Hygiene Habits of Disabled Persons: Relevance of the Carer's Personal Appearance and Interest in Oral Health. International Journal of Dental Hygiene 12 (2): 121-26. https://doi.org/10.1111/idh.12033.

Leite M., Aznar L., Ferreira M., Guaré R. \& Santos M. (2013). Increased salivary immunoglobulin $\mathrm{A}$ and reduced $\alpha$-amylase activity in whole saliva from spastic cerebral palsy individuals. Journal of Oral Pathology and Medicine 42, 480-5. https://doi.org/10.1111/jop.12047.

Makkar, A., Indushekar, K. R., Saraf, B. G., Sardana, D., \& Sheoran, N. (2019). A cross sectional study to evaluate the oral health status of children with intellectual disabilities in the National Capital Region of India (Delhi-NCR). Journal of Intellectual Disability Research, 63(1), 3139.

Maria, C., Pereira, G., Maria De, S., \& Faria, M .(2013). Emotional Development in Children with Intellectual Disability - A Comparative Approach with "Normal" Children. Journal of Modern Education Review, 3(2), 2155-7993.

Mazecaite-Vaitilaviciene, Laura, and Janine Owens. (2018). Children with Disabilities at Risk of Poor Oral Health in the Republic of Lithuania: A Retrospective Descriptive Service Evaluation. World Medical and Health Policy 10 (3): 246-58. https://doi.org/10.1002/wmh3.275.

Mundhenke, Lotta, Liselotte Hermansson, Qvist $\mathrm{Na}$, and Birgitta Sjo. (2014) .Experiences of Swedish Children with Disabilities: Activities and Social Support in Daily Life. Scandinavian Journal of Occupational Therapy, 17, 130-139.no. June 2009. 
https://doi.org/10.3109/110381209031143 86.

Ramawati. (2011). Faktor-faktor yang behubungan dengan kemampuan per watan diri anak tuna grahita di kabupaten Banyumas Jawa Tengah. (Unpublished Tesis), Univesitas Indonesia

Rinald, Katherine, and Pat Mirenda. (2012). Effectiveness of a Modified Rapid Toilet Training Workshop for Parents of Children with Developmental Disabilities.Research in Developmental Disabilities 33 (3): 933-43. https://doi.org/10.1016/j.ridd.2012.01.003.

Santos M., Ferreira M., Guaré R., Diniz M., Rösing C., Rodrigues J. et al. (2016) Gingivitis and salivary osmolality in children with cerebral palsy. International Journal of Paediatric Dentistry 26, 46370. https://doi.org/10.1111/ipd.12220.

Santos M., Ferreira M., Mendes F. \& de Oliveira Guaré R. (2014). Assessing salivary osmolality as a caries risk indicator in cerebral palsy children. International Journal of Paediatric Dentistry. 24, 84-9. https://doi.org/10.1111/ipd.12030.

Sinha N., Singh B., Chhabra K. G. \& Patil S. (2015). Comparison of oral health status between children withcerebral palsy and normal children in India: a case-control study. Journal of Indian Society of Periodontology $\quad 19, \quad 78-82$. https://doi.org/10.4103/0972124X.145800.

Subramaniam P., Mohan Das L. \& Girish Babu K. L. (2014). Assessment of salivary total antioxidant levels and oral health status in children with cerebral palsy. Journal of Clinical Pediatric Dentistry 38, 235-9. https://doi.org/10.1111/scd.12054.

Suparno \& Purwanto. (2007). Buku ajar cetak: Pendidikan berkebutuhan khusus. Departemen Pendidikan Nasional: Jakarta.

Sparrow, S. S., Cicchetti, D. V., \& Balla, D. A. (2005). Vineland adaptive behavior scales (2nd ed.). Circle Pines: AGS Publishing

Tan, S. S., Van Meeteren, J., Ketelaar, M., Schuengel, C., Reinders-Messelink, H. A., Raat, H., ... Roebroeck, M. E. (2014). Long-term trajectories of health-related quality of life in individuals with cerebral palsy: A Multicenter longitudinal study. Archives of Physical Medicine andRehabilitation, 95(11), 2029-2039. https://doi.org/10.1016/j.apmr.2014.04.031

Wertalik, Jennifer L., and Richard M. Kubina. (2017). Interventions to Improve Personal Care Skills for Individuals with Autism: A Review of the Literature. Review Journal of Autism and Developmental Disorders 4 (1): 50-60. https://doi.org/10.1007/s40489016-0097-6.

Wilson, N. J., S. Cumella, T. R. Parmenter, R. J. Stancliffe, and R. P. Shuttleworth. (2009). Penile Hygiene: Puberty, Paraphimosis and Personal Care for Men and Boys with an Intellectual Disability. Journal of Intellectual Disability Research 53 (2). https://doi.org/10.1111/j.13652788.2008.01133.x.

World Health Organization. (2011). World Repport on Disability. 